\title{
QUEEN'S
UNIVERSITY
BELFAST
}

\section{Creating an Inclusive Society... How Close are We in Relation to Autism Spectrum Disorder? A General Population Survey}

Dillenburger, K., McKerr, L., Jordan, J. A., Devine, P., \& Keenan, M. (2015). Creating an Inclusive Society... How Close are We in Relation to Autism Spectrum Disorder? A General Population Survey. Journal of Applied Research in Intellectual Disabilities, 28(4), 330-340. https://doi.org/10.1111/jar.12144

Published in:

Journal of Applied Research in Intellectual Disabilities

Document Version:

Early version, also known as pre-print

Queen's University Belfast - Research Portal:

Link to publication record in Queen's University Belfast Research Portal

Publisher rights

Copyright 2015 The Authors

Upon publication include this statement- This is the pre-peer reviewed version of the following article: Dillenburger, K., McKerr, L., Jordan, J. A., Devine, P. and Keenan, M. (2015), Creating an Inclusive Society... How Close are We in Relation to Autism Spectrum Disorder? A General Population Survey. Journal of Applied Research in Intellectual Disabilities, 28: 330-340., which has been published in final form at http://onlinelibrary.wiley.com/doi/10.1111/jar.12144/abstract

\section{General rights}

Copyright for the publications made accessible via the Queen's University Belfast Research Portal is retained by the author(s) and / or other copyright owners and it is a condition of accessing these publications that users recognise and abide by the legal requirements associated with these rights.

Take down policy

The Research Portal is Queen's institutional repository that provides access to Queen's research output. Every effort has been made to ensure that content in the Research Portal does not infringe any person's rights, or applicable UK laws. If you discover content in the

Research Portal that you believe breaches copyright or violates any law, please contact openaccess@qub.ac.uk. 
Creating an inclusive society... How close are we in relation to Autism Spectrum Disorder?

A general population survey.

Dillenburger, K., McKerr, L., \& Jordan, J.A.

Journal of Applied Research in Intellectual Disabilities (2014)

\begin{abstract}
Children with Autism Spectrum Disorder are increasingly educated in mainstream classrooms in the United Kingdom (Wilkinson \& Twist, 2010) and some employers are now specifically seeking out staff on the autism spectrum. Does that mean that we are living in an 'inclusive society' (United Nations Department of Economic and Social Affairs [UNDESA], 2008), in the sense that inequalities are reduced and full economic, social and cultural participation is advanced for individuals with autism? We conducted a general population survey to assess how close we are to an inclusive society for individuals with autism in Northern Ireland. We examined public attitudes to (a) visibility and social interaction, (b) aetiology, needs, and interventions, and (c) rights and resources.

A stratified, representative sample of 1204 adults took part in the survey; of these, 989 were aware of autism and their attitudes and behavioural projections reflected a mix of acceptance and denunciation. The level of confusion with regards to interventions reflected the general uncertainty within UK policy regarding meeting the needs of individuals on the autism spectrum. Therefore, it seems that inclusion is working to an extent, but more clarity is needed with regard to adequate education, intervention, and support for individuals with autism.
\end{abstract}

Keywords: autism, inclusion, population survey 
Creating an inclusive society... How close are we in relation to Autism Spectrum Disorder? A general population survey.

Creating an inclusive society is a dynamic process 'aimed at lowering economic, social and cultural boundaries, or making boundaries more permeable' (United Nations Department of Economic and Social Affairs [UNDESA], 2008, p.5). Social inclusivity can be measured on a number of dimensions, including visibility and access to social interaction with others, consideration of needs and rights, such as the right to be different, to work and to participate in the cultural life of society, and the resources to enable people to exercise these rights (ibid.). An inclusive society therefore is one in which 'every individual, each with rights and responsibilities, has an active role to play' (United Nations [UN], 1995, p.68). Improving opportunities for social inclusion has been identified as a key objective for education as well as health and social care providers (Bamford, 2005).

There are many barriers to a fully inclusive society and these vary according to the cultural and economic structures of communities; ultimately, inclusivity requires a strong public commitment. Against the background of requirements for social inclusion policies within United Nations member states (UNDESA, 2010; United Nations Educational, Scientific and Cultural Organisation [UNESCO], 2013), we explored how far the public had adopted positive attitudes towards social inclusion of individuals with autism in regard to (a) visibility and access to social interaction, (b) causes, needs, and interventions, and (c) rights and resources, including the rights to be different, to work, and to participate in the cultural life of society.

Autism spectrum disorder (ASD), a pervasive developmental disorder, is characterised by challenges in social communication, restricted interests and repetitive behaviours (APA, 2013). The exact aetiology of autism is not known, although genetic as well as environmental factors, 
including the prenatal environment, clearly play a role (Medical Research Council [MRC], 2001;

Szatmari et al., 2007). The quality of parenting (Siller \& Sigman, 2002; Yirmiya \& Sigman, 2001) and vaccinations have not been linked with autism aetiology (Demicheli, Rivetti, Debalini, \& Pietrantonj, 2012; Wilson, Mills, Ross, McGowan, \& Jadad, 2003). The term ‘high functioning' refers individuals with autism who have an average or above average IQ, a high degree of independence, but socialising difficulties, while 'low functioning' refers to individuals who experience serious difficulties and lack of independence, co-occurring intellectual disabilities as well as significant problems in socialising (Baio, 2012).

Although some still view autism as inevitably a lifelong disability (Klin, Saulnier, Sparrow, Cicchetti, Volkmar, \& Lord, 2007; Mesibov, Shea, \& Schopler, 2004; Rogers 1996), there now is sufficient evidence that, with early intensive interventions based on the application of behaviour analysis (Orinstein et al., 2014; Vismara \& Rogers, 2010), individuals with autism can reach ambitious outcomes to the extent that about $20 \%$ no longer meet diagnostic criteria (Fein et al., 2013; Seltzer, Krauss, Shattuck, Orsmond, Swe, \& Lord, 2003).

Making friends constitutes one of the areas that cause problems for individuals with ASD. Only $1 \%$ of typically developing children do not have friends (Office for National Statistics [ONS], 2005; Swearer, Wang, Maag, Siebecker, \& Frerichs, 2012), compared to $42 \%$ of children with autism (Solish, Perry, \& Minnes, 2010), although children with ASD are increasingly educated in mainstream classrooms (Wilkinson \& Twist, 2010) and some employers are now specifically seeking out staff on the autism spectrum (Vasagar, 2013). Bullying is another major concern (Chamberlain, George, Golden, Walker, \& Benton 2010; DCSF 2010); children with autism are four times more likely to be bullied than other children (Little, 2002; Sofronoff, Dark, \& Stone 2011). Strong reactions to being teased (Sofronoff et al., 2011) and 
atypical interests (Gray, 2004) increase the risk of being ostracized. In special schools, bullying is less likely (van Roekel, Scholte, \& Didden, 2010), possibly because of greater acceptance of difference (Due et al., 2005) or higher teacher: pupil ratios (Zablotsky, Bradshaw, Anderson, \& Law, 2012).

Mental health problems including anxiety, hyperactivity, self-injurious and stereotypic behaviours, low self-esteem, over sensitivity, and suicidal ideation (Batten, Corbett, Rosenblatt, Withers, \& Yuill, 2006; Cappadocia, Weiss, \& Pepier, 2012) mean that one quarter of children with autism self-harm or attempt suicide; twelve times more than other children (ONS, 2005).

Unfortunately, things do not seem to get better as children with ASD grow up. Many adults with autism still have difficulty making friends (Howlin, Goode, Hutton, \& Rutter, 2004; Stewart, 2008) and face social exclusion; over 50\% report that they have been bullied or harassed at some point in their life (Rosenblatt, 2008). Social ostracization does not reflect a lack of desire to have friends on the part of individuals with autism; on the contrary, the vast majority of adults and children with autism want to spend more time socialising (Bauminger \& Kasari, 2000; Stewart, 2008).

Living actively and as independently as possible within the community is an essential aspect of inclusion, yet $44 \%$ of adults with autism live at home with their aging parents, one third live in residential care, and 17\% lived in some form of supported housing (Broach, Camgoz, Heather, Owen, Potter, \& Prior, 2003). Over 70\% of older caregivers (aged $60+$ years of age) have not made any plans for the future of their adult son or daughter with disabilities (Dillenburger \& McKerr, 2011). The policy-based move away from residential or institutional accommodation has been welcomed but ultimately, its success depends on positive public attitudes towards inclusion. 
Obviously, on legal grounds individuals with ASD have the same rights as any other human being, including the rights to be different, to work, and to participate in the cultural life of society (United Nations Convention on the Rights of Persons with Disabilities [UNCRPD], 2006; United Nations Convention on the Rights of the Child [UNCRC], 1989; UNDESA, 2008) but they may require individually tailored resources to be able to avail of these rights. For children on the autism spectrum, the necessary resources should largely be linked to early effective and evidence-based support and interventions at home and at school (National Autism Centre, 2009). For adults with autism, attaining gainful employment is one of the best ways to ensure inclusion, social interaction, and financial independence.

The right to protection from discrimination in employment, during training, recruitment, and continuing education is enshrined in the UNCRPD (2006). Yet, Rosenblatt (2008) found that only $15 \%$ of adults with ASD were in full time employment. These low employment rates are not a reflection of a lack of willingness to work, i.e., the majority of adults with ASD want to work (Barnard, Harvey, Potter \& Prior, 2001; Dillenburger \& McKerr 2011), but those who find work are usually employed in low skilled, poorly paid jobs (Howlin et al., 2004). While undoubtedly employment on the 'open market' is the aim, supported employment programmes seem to enhance the chances of some adults with autism obtaining a well-matched job (Howlin, Alcock, \& Burkin, 2005).

Ultimately, unemployment is not only detrimental for the individual themselves, it actually represents $36 \%$ of the estimated annual cost of the $£ 25$ billion required for supporting adults with autism and their families in the U.K. (Knapp, Romeo, \& Beecham 2009), with similar pro rata figures in the U.S. (Consulting SE, 2011) and Australia (Ganz, 2007). 


\section{Public attitudes}

Raising public awareness of autism spectrum has been the focus of many autism charities and government policies, for example, Autism Speaks' international Light it up Blue Campaign (2013) has global appeal and worldwide take-up. These campaigns seemed to have been rather successful and recent research has shown that more than $80 \%$ of the public now are aware of autism and for example in Northern Ireland, approximately $60 \%$ of the general public actually have someone on the autism spectrum in their family or in their close circle of friends (Dillenburger, Jordan, McKerr, Devine, \& Keenan, 2013). However, less is known about how the general public feel about individuals with autism or what their attitudes are towards inclusion.

To our knowledge, the only other large-scale general population survey of attitudes towards individuals with ASD to-date is a French survey of 1,000 people that showed that most people had positive attitudes towards individuals with autism (Durand-Zaleski, Scott, Rouillon, \& Leboyer, 2012). Given that this was a non-randomised open access online survey, it is not surprising that $100 \%$ awareness of autism was recorded, i.e., only computer literate people who were aware of autism responded. This limitation probably explains many of the findings, for example, more than $90 \%$ of the respondents felt that individuals on the autism spectrum would be able to live in the community and only $3 \%$ stated that they would not want their child to be in the same class at school as a child with autism. When asked about employment issues, only about one quarter of the respondents believed that someone with autism was unable to work, and only $6 \%$ said that they would not be willing to work with someone with autism. Given the 
enormous difference in abilities across the autism spectrum it is surprising that the French study did not differentiate between levels of functioning.

The French sample thought the likely causes of autism were genetics (44\%), parent-child relations $(22 \%)$, or the environment $(11 \%)$. It is important to note here that in France autism interventions are mainly carried out by psychiatrists promoting a psychoanalytic approach, and out-dated theories, for example, the belief that autism is caused by the 'refrigerator mother', still prevail widely (Schofield, 2012). Not surprisingly, when asked about the life course of autism most respondents were not optimistic and felt that life-long support would be needed (61\%). Only few of the respondents felt that with treatment someone with autism could lead a 'normal life' $(25 \%)$.

In contrast, the present study was part of a representative large-scale general population survey, the Northern Ireland Life and Times (NILT) Survey that is carried out in Northern Ireland annually. In 2012, the NILT Survey included for the first time, questions related to ASD that examined awareness and knowledge of and attitudes and behavioural estimations towards individuals with ASD. Findings regarding public awareness and knowledge were reported elsewhere (Dillenburger et al., 2013). This paper focuses on attitudes towards (1) visibility and social interaction, (2) consideration of needs, and (3) rights and resources.

\section{Method}

\section{Participants}

1,204 adults aged 18 years or over living in private households took part in the 2012 Northern Ireland Life and Times (NILT) survey (representing a response rate of 57\%). Data were weighted by household size to make the data representative of the Northern Irish (NI) population 
(as per the 2011 NI Census of Population figures) (Devine, 2013). The proportion of females was slightly higher than that of males ( $54.6 \%$ vs $45.6 \%)$; the age distribution was fairly normal, just over one quarter (27\%) of the participants were 18-34 years of age, 52\% were 35-64 years of age, and $21 \%$ of the participants were 65 years or older.

\section{Research tool and procedure}

The Northern Ireland Life and Times (NILT) Survey is an annual population survey that is carried out on a stratified sample of adults in Northern Ireland. The survey gathers demographic data on respondents, such as age and gender, and consists of a number of different modules, each year addressing pertinent community concerns. An ASD module was included for the first time in NILT 2012, focussing on public awareness, knowledge, attitudes, and behaviours towards individuals on the autism spectrum in a variety of contexts including social, employment, education, and housing. Participants completed the ASD module along with the other NILT modules. NILT modules primarily contain questions with fixed choice response options; some open ended questions are also included. The main purpose of the survey is to produce reliable estimates of the public's attitudes rather than to explore attitudes in depth, this means that if a respondent replied 'don't know' or 'sometimes' to a question, no further information was sought.

A two-stage selection system was used. First, in a systematic random sampling procedure, 2,346 Northern Irish private household addresses were selected from the Postcode Address File (PAF); second, in cases where more than one adult lived at the address, the person with the next due birthday was selected as respondent; if the chosen respondent was not available, a suitable alternative time was arranged for interview. Participants selected for the 
survey received a letter explaining the purpose of the study and providing contact details of the survey management team.

While the research team, in consultation with service users, autism charities, and the funder, developed the survey questions, the persons carrying out the interviews were employed by an independent fieldwork agency that was unrelated to the researchers or the funders of the research. The interviewers were experienced in survey research and were trained in the use of the computer assisted personal face-to-face interview techniques.

An iPad was used for data entry during the interview. The main questionnaire was completed by the interviewer registering participant responses on the iPad. In addition, a short self-completion questionnaire was completed by the respondent using the iPad themselves, although the interviewer could administer this questionnaire, if requested by the respondent.

NILT 2012, including the ASD module, was piloted with 60 respondents in August/September 2012. There were no major changes to the final version of the ASD module. Main survey interviews were carried out from $1^{\text {st }}$ October 2012 to $10^{\text {th }}$ January 2013 . Results for all modules, questionnaires, datasets, definitions, and technical information are freely accessible on the NILT website (www.ark.ac.uk/nilt).

\section{Data analysis}

Data underwent an extensive range of inter- and intra-variable logic checks and results reported here have been weighted to account for household size. Data presented here are based on the 989 participants who said that they had heard of autism, Autism Spectrum Disorder or Asperger's Syndrome. 


\section{Results}

\section{Visibility and access to social interaction}

Generally speaking we found very positive attitudes towards children with autism; 93\% of respondents said they would be comfortable if a family with a child with autism would move next door to them and $92 \%$ said they would feel comfortable if a child with autism were in the same class as their child. When asked about children with high functioning autism the positive attitudes increased by another 4 percentage points in both cases.

With regard to adults with autism the survey also identified very positive public attitudes. Most respondents said that they would feel comfortable if an adult with autism moved in next door on their own $(83 \%)$, married a close relative $(80 \%)$, or was a work colleague $(81 \%)$. Nearly three quarters $(71 \%)$ of participants stated that they would be comfortable if someone with autism was appointed as their boss. These figures increased to near $90 \%$ or above, when asked specifically about these issues with regard to individuals with high functioning autism.

\section{Causes and interventions}

The opinions expressed by the participants about what causes autism reflected the fact that, at present, no specific cause has been identified (Figure 1). Nearly two thirds of participants did not think that autism was caused by environmental factors (59\%); only very few people thought it was (7\%). Similarly, very few participants thought that autism was caused by vaccines like MMR (7\%). Respondents were split over the issue of genetic causes. While $41 \%$ of respondents thought that autism could be inherited, many disagreed $(26 \%)$, were unsure $(20 \%)$ or 
did not express an opinion (13\%). Respondents agreed overwhelmingly that autism was not caused by poor parenting ( $84 \%$ ); only $3 \%$ believed that autism was associated with the quality of parenting.

Figure 1. Beliefs about the causes of autism.

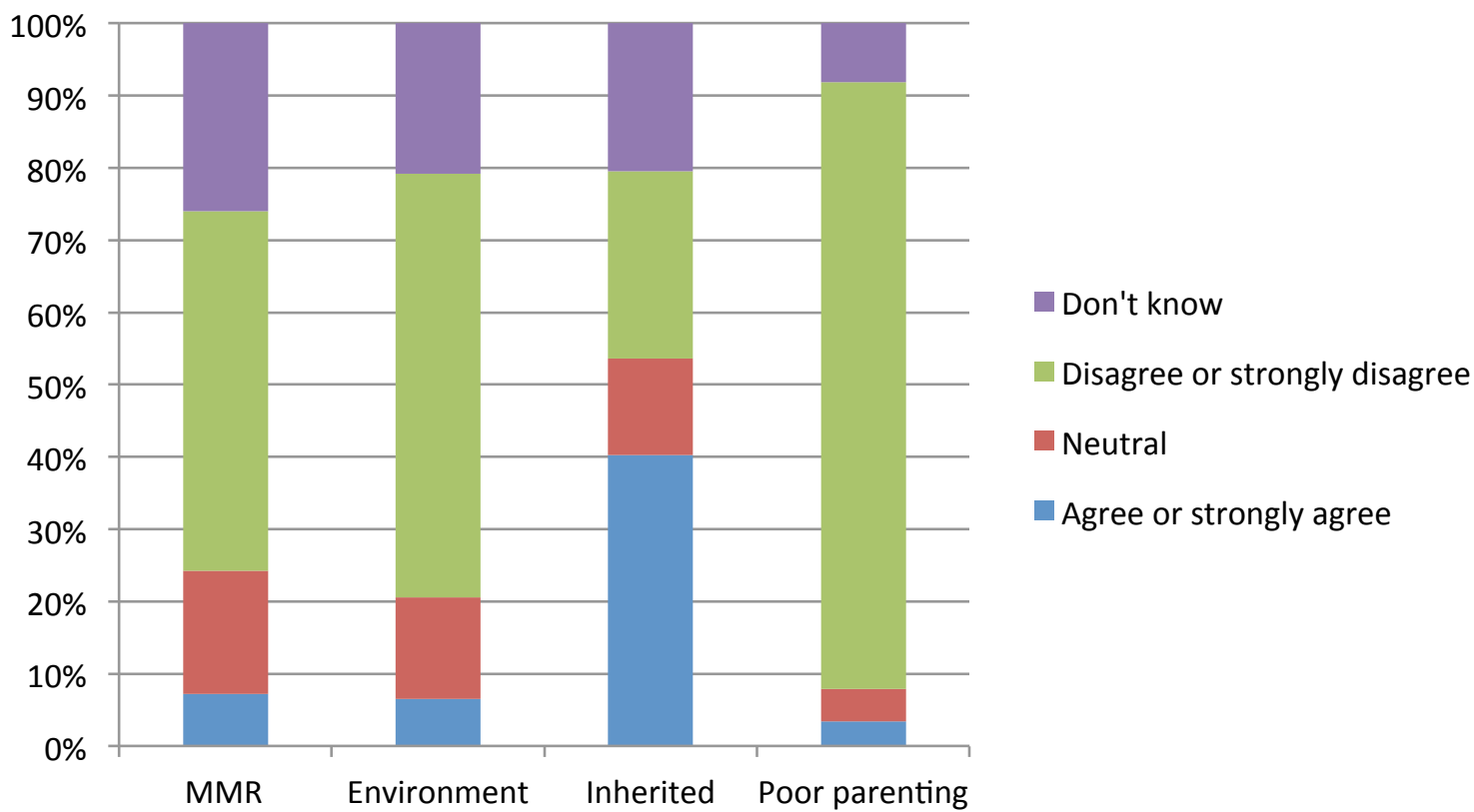

The public view of the lifetime trajectory for individuals with autism is influenced by the fact that autism is frequently defined as a 'lifelong disability' (Hill \& Frith, 2003; Klin et al., 2007; Rogers, 1996) and autism charities (Autism NI, 2013; NAS, 2013). In fact, some intervention programmes are based on this concept of autism (Mesibov et al., 2004). The most recent NICE guidelines (2013) replaces the term 'lifelong', describing autism as 'a chronic disorder with lifelong disability in some individuals' (p.26).

This use of the term 'lifelong' in the context of autism is intriguing because no other condition or disability is prefixed with 'lifelong', i.e., we do not speak of 'lifelong Down 
Syndrome' or 'lifelong epilepsy'. The use of the term 'lifelong' with regards to autism originated from a concern that autism was viewed solely as a childhood disorder and is justified by the fact that there are many adults with autism. In spite of this, it has the potential to put a cap on expectations and therefore we wanted to know how the public felt about the term 'lifelong' with reference to autism. As Figure 2 shows, more than half of respondents (58\%) either disagreed or strongly disagreed that autism is a lifelong disability The remaining respondents either agreed or strongly agreed with this statement $(22 \%)$, were neutral $(12 \%)$, or unsure $(8 \%)$.

Figure 2 Attitudes towards lifelong issues including residential care and making independent choices

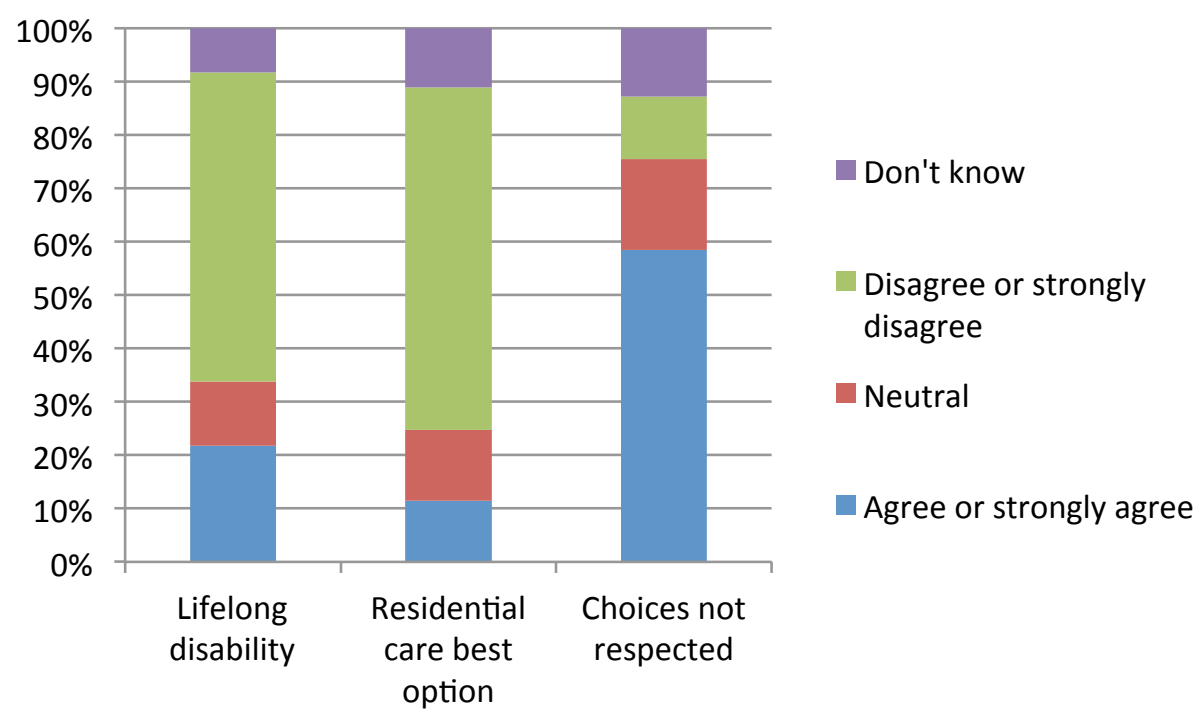

With regards to how the public viewed the potential for inclusion, social interaction, and independence for individuals with autism, most respondents disagreed or strongly disagreed with the statement that residential care was the best option for someone with severe autism and their families (64\%) and relatively few participants strongly agreed or agreed with that statement (12\%). Most participants either agreed or strongly agreed (58\%) with the statement 'when 
someone has autism their choices are not respected enough', while $17 \%$ were neutral, $13 \%$ were unsure, and $12 \%$ disagreed or strongly disagreed.

\section{Consideration of needs}

Regarding interventions or treatment for autism, $50 \%$ of the participants thought that drug treatments were effective, while the other half of respondents either disagreed, were neutral or unsure (Figure 3). Participants showed strong support for behavioural interventions with over three quarters (77\%) agreeing that behavioural interventions were effective. Very few participants disagreed with the statement that behavioural interventions were effective; some respondents did not know. Concerning other non-drug related support, nearly three quarters (74\%) thought that other non-drug treatments could be effective, although some disagreed or did not know. Of course, these data are not evidence of effectiveness; instead they are merely evidence of public perception of need. The vast majority of respondents $(80 \%)$ disagreed with the statement that there was nothing that can help individuals with autism. Very few participants thought that individuals with autism did not require some kind of help or intervention. 
Figure 3. Views on support and intervention for people with autism

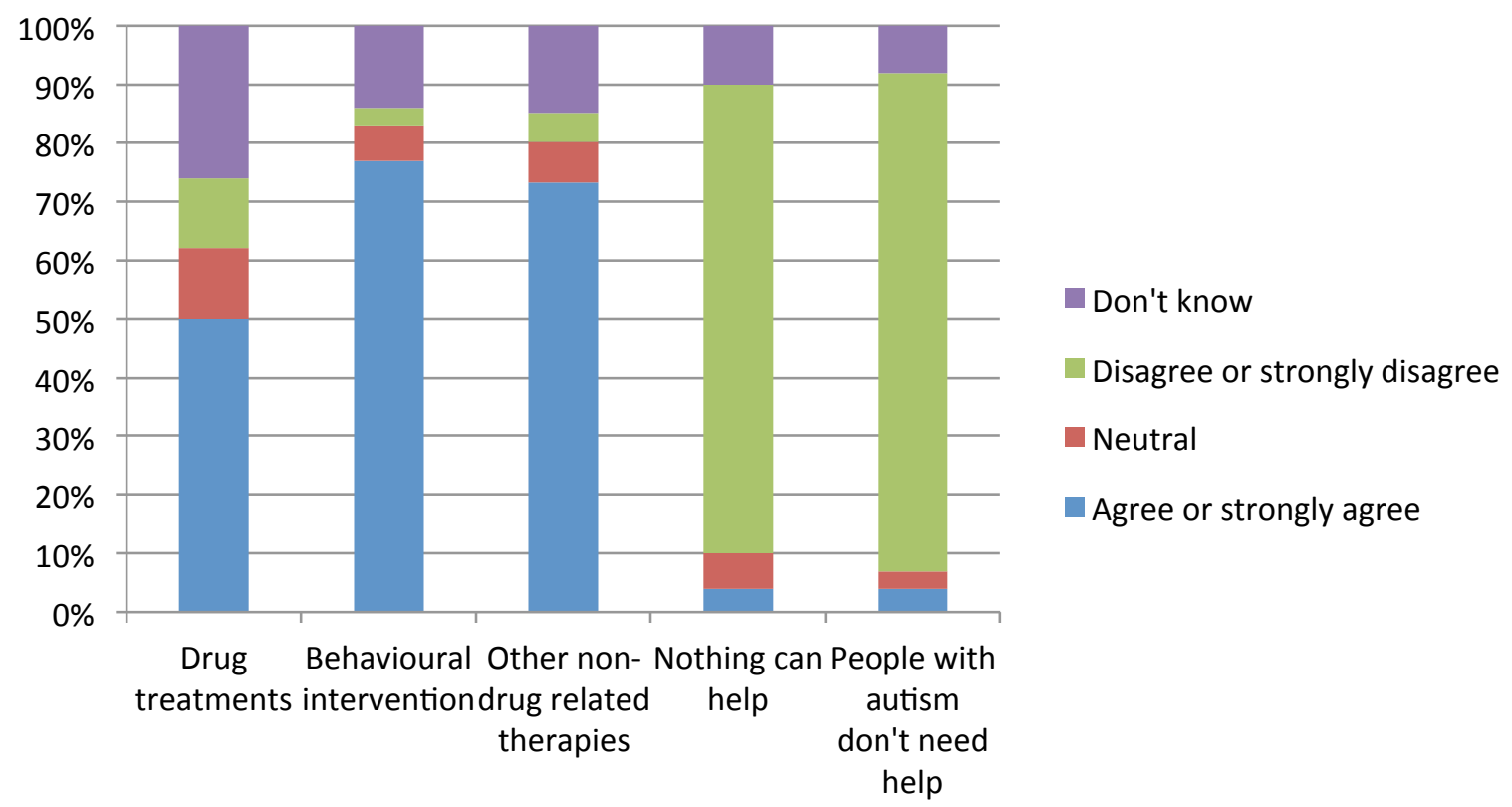

\section{Rights and resources}

An important factor with regard to inclusion is public perception of ability of individuals on the autism spectrum to function in a socially relevant employment setting. Participants were asked to indicate which jobs they felt individuals with autism, especially those who were high functioning, could perform satisfactorily. We included a list of jobs (Figure 4), ranging from relatively low skilled, to manual, and to highly skilled, to explore if the public viewed certain types of jobs as suitable for someone with autism. 
Figure 4. Views on the suitability of different job types for individuals with autism

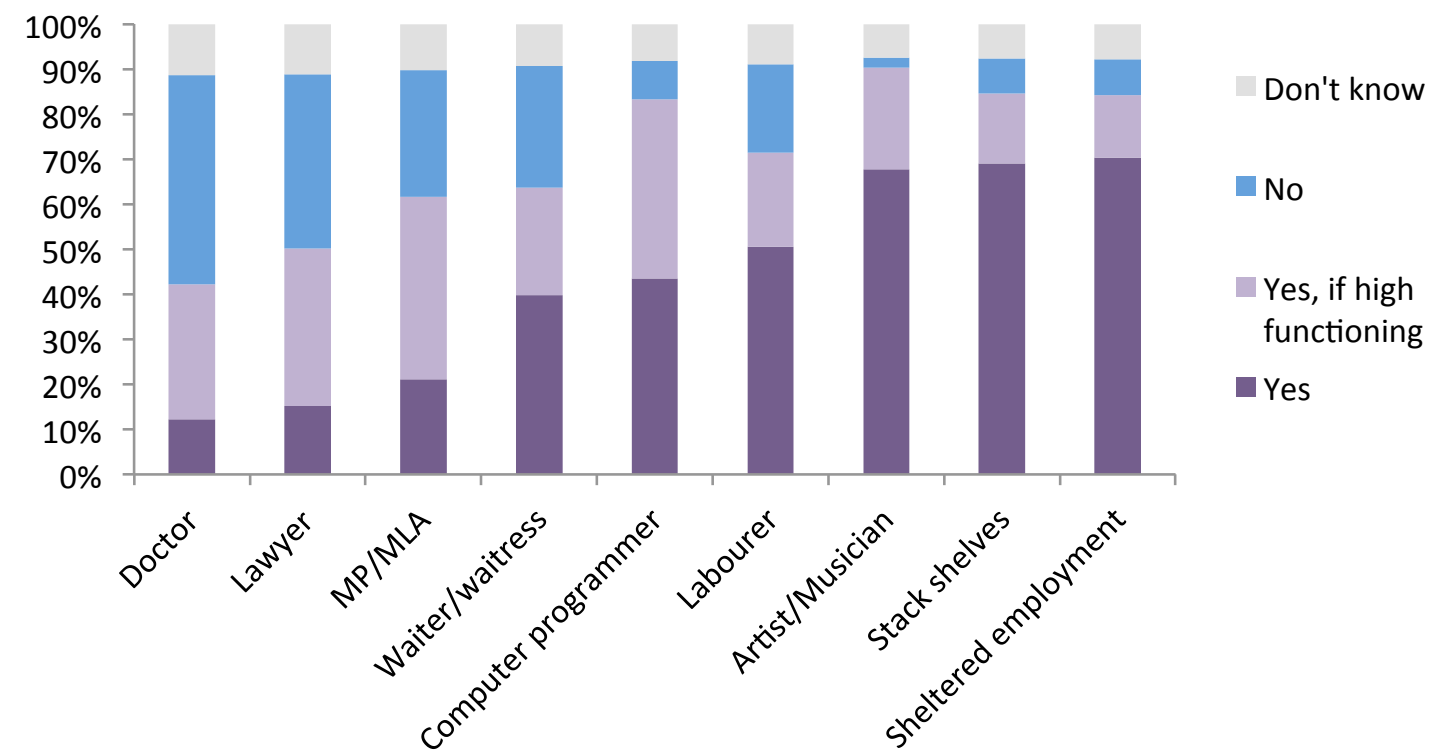

The majority of the public agreed that the following jobs could be suitable especially for someone who was high functioning: computer programmer (83\%), artist/musician (90\%), shelf stacker (85\%), sheltered employment (84\%), labourer (71\%), or waiter/waitress $(64 \%)$.

However, there was less agreement amongst respondents as to suitability for individuals with autism for some highly skilled and socially demanding and responsible jobs, such as doctor $(42 \%)$, member of the parliament or assembly (62\%), and lawyer (50\%), although many felt that these jobs could be suitable for high functioning individuals with autism. The public also felt that some jobs are suitable for someone with autism regardless of level of functioning (for example, artist/musician).

Friedman's ANOVA revealed a significant difference in the suitability ratings that the public assigned to the nine professions $(x 2(8)=2457.41, \mathrm{p}<.001)$. Post hoc analysis using Wilcoxon tests indicated little to negligible difference (all small effect sizes) between attitudes towards the appropriateness of jobs such as artist/musician, stacking shelves, and sheltered employment. Relative to member of parliament/assembly, lawyer and doctor, significantly 
higher suitability ratings $(\mathrm{p}<.001)$ were found for artist/musician $(\mathrm{r}=.46-.52)$, stacking shelves $(\mathrm{r}=.44-.50)$, and sheltered employment $(\mathrm{r}=.44-.51)$, all comparisons produced medium to large effect sizes. The public also rated artist/musician $(r=28-.37)$, stacking shelves $(r=.22$ $35)$, and sheltered employment $(\mathrm{r}=.25-.35)$ as more suitable than labourer, programmer, and waiter, albeit to a lesser extent as evidenced by the more modest effect sizes.

Considering the potential of business owners worrying about losing business if they employed someone with autism, the relatively innocuous example of a 'supermarket' was used as a business that is frequently used by nearly everyone and where most staff have direct contact with customers. Respondents were asked how it would affect their shopping behaviour if a supermarket decided to introduce a policy on employing people with autism. While the majority of respondents ( $86 \%)$ said that if a supermarket employed someone with autism it would make no difference to them, more than one in ten of the respondents said that they would be more likely to shop in a supermarket that employs someone with autism (12\%). Less than $1 \%$ of people said that they would be less likely to shop in a supermarket that employed someone with autism.

Over three quarters of participants felt that individuals with high functioning autism should definitely (46\%) or probably (32\%) be encouraged to live independently, while $83 \%$ of the respondents felt that they should definitely (49\%) or probably (34\%) be encouraged to learn to drive a car. 


\section{Discussion}

A general population study was conducted to explore attitudes of the general public regarding inclusion of individuals with autism; 1,204 adults completed the survey in Northern Ireland; $82 \%(\mathrm{n}=989)$ respondents were aware of autism and their views were explored regarding autism and (a) visibility and access to social interaction, (b) consideration of needs, and (c) rights and resources.

Results showed that the general public was accepting and comfortable with living, working, and educating inclusively together with individuals with autism. In general, positive and inclusive attitudes and a commitment to a more inclusive society were expressed with regard to the participation of children and adults with autism in community and social life. Positive attitudes were expressed towards parents who have children with autism, with very few members of the public still believing that poor parenting could cause autism. Instead, consistent with Durand-Zaleski et al. (2012) in France, the public in Northern Ireland were most likely to think that autism is inherited, a proposition that has at least some levels of scientific support (MRC, 2001).

With respect to social interaction and participation in community life, the vast majority of NILT respondents thought that there would be a need for some degree of support, depending on the particular individual. These views were consistent with the research in the area (Stewart, 2008; Keenan, Dillenburger, Doherty, Byrne, \& Gallagher, 2010). However, many of the participants thought that drugs would be effective. This view is out of line with the fact that there are no drugs that effectively treat the core features of autism (Warren et al., 2011). 
There was strong support for behaviour-based interventions. This is encouraging, since nearly all evidence-based interventions are based on the scientific discipline of applied behaviour analysis (National Autism Centre, 2009; Vismara \& Rogers, 2013). However, there also was support for eclecticism and 'other' non-pharmacological interventions that have been shown to lack effectiveness (Howard, Sparkman, Cohen, Green, \& Stanislaw, 2005). This finding is not surprising given the persistent misrepresentation of behaviour analysis-based interventions (Jordan, 2012; Howlin, 2013) and the resultant reluctance of NI government and public bodies to embrace international best practice, while stubbornly promoting an ill-defined eclectic approach (Task Group Report on Autism; Department of Education, 2002). Therefore, the public view expressed with regards to eclecticism may not represent that held in jurisdictions that have embraced behaviour analysis as the basis for interventions, such as most of USA and Canada.

The idea that autism is necessarily a lifelong disability was not supported in the public view. This is interesting, given prevailing medical approach that persistently views autism as lifelong disability (NICE, 2013) despite research findings to the contrary (Helt et al., 2008; Fein et al., 2013; Orinstein et al., 2014). It seems that the public is more ambitious, yet realistic, for individuals with ASD than governments or professionals. This positive pro-active public attitude is supported by parents' experiences (Lamb, 2009; Dillenburger, Keenan, Doherty, Byrne, \& Gallagher, 2010) and scientific evidence (Helt et al., 2013).

The right to work is another important dimension of inclusion and individuals with autism clearly face many barriers to employment as evidenced by the employment rate of $15 \%$ (Rosenblatt, 2008). In order to gain employment, individuals with autism may need specific help and personal support and, once they have found a job, they may need on-going support getting to work, adjusting to the employment setting, and relating to their co-employees. Employers and 
employees need training relating to possible idiosyncrasies of their new work colleague and the resources to facilitate these adjustments are not always easily available (Bancroft et al., 2012; Forsythe, Rahim, \& Bell, 2008).

It was encouraging to see that the vast majority of survey respondents would be comfortable working with someone with autism. This was consistent with findings in other attitude surveys (Durand-Zaleski et al., 2012; Stewart, 2008) as was the fact that NILT respondents considered all kinds of jobs suitable for individuals with autism, especially if the individual was high functioning (Howlin et al., 2005).

A highly significant finding for employers was the fact that $12 \%$ of respondents stated that they would be more likely to give business to an employer who actively employs people with autism. Thus, employers should feel confident about actively employing people with autism. A good example is the German software company SAP (Systems, Applications, and Products in Data Processing), who actively seek to employ individuals with autism (Vasagar, 2013). This firm has recognised and is confident that individuals with autism can offer a unique contribution to the productivity of the firm through their attention to detail and accuracy in data analysis. SAP have entered into partnership with Specialisterne, a Danish company that has established a data software testing model employing people with autism; Specialisterne currently has branches in Germany, Iceland, Switzerland, the United States, and the Republic of Ireland (Dillenburger, McKerr, \& Jordan, 2014; Hodson, 2013; Thygesen, 2012). Another example is Vodafone Germany in partnership with Auticon, who specialise in placing and mentoring people with autism in employment in the information technology industry (Evans, 2013). Smaller localized examples also exist, such as The Undiscovered Workforce campaign currently run by 
the NAS in Cambridge that brings together people with autism and local employers (Huppert, 2013). Clearly, public attitude supports these efforts.

An inclusive society takes into consideration the right to fully participate in the social and cultural life of the community. Results reported here showed that most people disagreed that residential care was the best option for someone with severe autism and their families. These views are consistent with the preferences of families (Taggart, Truesdale-kennedy, Ryan, \& McConkey, 2012) and Government policy (DHSSPSNI, 2010; 2011; Northern Ireland Executive, 2012).

More than half of the respondents felt that the rights of individuals with autism were not respected enough. These views are not surprising in view of the social and communication difficulties that define the condition and the fact that only one in ten adults with autism receive advocacy support, fewer than half of those who need an advocate (Broach et al., 2003).

\section{Conclusion}

To conclude, results reported here represent the attitudes and opinions of adults in the general population in Northern Ireland. Similar surveys are underway to explore views of young people and children.

Survey findings are by definition self-reports; they do not necessarily imply positive behaviours (Lloyd, 1994). Individuals with autism still are commonly bullied in schools and in the workplace (Bancroft, Batten, Lambert, \& Madders, 2012; Rosenblatt, 2008). It could be the case that, as in most cases of bullying, these are the actions of only a few people with negative attitudes towards individuals with autism. It is also possible that people express positive attitudes but their public behaviours are intentionally or unintentionally incongruent with these attitudes. 
Research has shown a long time ago that the correspondence between what people say and what they do (say-do correspondence) is generally weak (Lloyd, 1994), and that perceived 'social desirability' in face-to-face interviews can affect responses (Richman, Kiesler, Weisband \& Drasgow,1999) These are difficult but important questions to address in future research.

In the meantime, in terms of visibility, access to social interaction, needs, rights, and resources, the general public in Northern Ireland have expressed broadly inclusive attitudes and general acceptance of individuals with autism, and acknowledged the right to participate in the social, educational and employment life of the community. Building on these relatively positive public attitudes will require accurately targeted, evidence-based support from both statutory and voluntary agencies to ensure that individuals with autism can play an active role in a truly inclusive society.

\section{References}

American Psychological Association (2013). Diagnostic Statistical Manual of Mental Disorders$5^{\text {th }}$ Edition. Retrieved from www.dsm5.org

Baio, J. (2012). Prevalence of autism spectrum disorders - autism and developmental disabilities monitoring network, 14 sites, United States, 2008. Surveillance Summaries, 61, 1.

Bamford, D. (2005). The Bamford Review of Mental Health and Learning Disability (NI): Equal Lives. Retrieved from www.dhsspsni.gov.uk/equallivesreport.pdf

Bancroft, K., Batten, A., Lambert, S., \& Madders, T. (2012).The way we are: Autism in 2012. London: National Autistic Society. 
Barnard, J., Harvey, V., Potter, D., \& Prior, A. (2001). Ignored or ineligible? The reality for adults with autism spectrum disorders. London: National Autistic Society.

Batten, A., Corbett, C., Rosenblatt, M., Withers, L., \& Yuille, R. (2006). Make school make sense. Autism and education: The reality for families today. London: National Autistic Society.

Bauminger, N., \& Kasari, C. (2000). Loneliness and friendship in high-functioning children with autism. Child development, 71, 447-456.

Behavior Analyst Certification Board (2013). Behavior Analyst Licensure/Certification Statutes. Retrieved from www.bacb.com/index.php?page $=100170$

Broach, S., Camgöz, S., Heather, C., Owen, G., Potter, D., \& Prior, A. (2003). Autism: Rights in reality - How people with autism spectrum disorders and their families are still missing out on their rights (England and Wales) - full report. London: National Autistic Society.

Cappadocia, M.C., Weiss, J.A., \& Pepier, D. (2012). Bullying experiences among children and youth with autism spectrum disorders. Journal of Autism and Developmental Disorders, 42, 266-277.

Chamberlain, T., George, N., Golden, S., Walker, F., \& Benton, T. (2010) Tellus4 national report (PDF). London: Department for Children, Schools and Families (DCSF).

Consulting SE (2007). Economic costs of autism spectrum disorders. Retrieved from http://aeiou.org.au/files/Cost\%20of\%20autism\%20report_FINAL_120507.pdf

Demicheli, V. Rivetti, A., Debalini, M.G., \& Di Pietrantonj, C. (2012). Vaccines for measles, mumps, and rubella in children (Review). Cochrane Database of Systematic Reviews, Issue 2. 
Department for Children, Schools and Families (2010). Local authority measures for national indicators supported by the Tellus4 survey. London: Department for Children, Schools and Families.

Department of Education 2002. Task Group Report on Autism. Belfast: Department of Education.

Department of Health, Social Services and Public Safety (2010). Care Management, Provision of Services and Charging Guidance 2010. Circular HSC (ECCU) 1/2010. Retrieved from www.dhsspsni.gov.uk/hsc-eccu-1-2010.pdf

Department of Health, Social Services and Public Safety (2011). Transforming Your Care: A Review of Health and Social Care in Northern Ireland (Compton Report). Retrieved from www.dhsspsni.gov.uk/transforming-your-care-reviewof-hsc-ni-final-report.pdf

Devine, P (2013). Northern Ireland Life and Times Survey 2012: Technical notes. Belfast: ARK. Retrieved from www.ark.ac.uk/nilt/2012/tech12.pdf.

Dillenburger, K., Jordan, J.A., McKerr, L., Devine, P., \& Keenan, M. (2013). Awareness and knowledge of autism and autism interventions: A general population survey. Research in Autism Spectrum Disorders 7, 1558-1567.

Dillenburger, K., Keenan, M., Doherty, A., Byrne, J., \& Gallagher, S. (2010). Living with children diagnosed with Autism Spectrum Disorder: Parental and professional views. British Journal of Special Education. 37, 13-23.

Dillenburger, K., \& McKerr, L. (2011). “How long are we able to go on?” Issues faced by older family caregivers of adults with disabilities. British Journal of Learning Disabilities, 39, pp.29-38. 
Dillenburger, K., McKerr, L. \& Jordan, J-A. (2014). Project ABLE: Evaluation report. Belfast: Queen's University Belfast.

Due, P., Holstein, B. E., Lynch, J., Diderichsen, F., NicGabhain, S., Scheidt, P., ...The Health Behaviour in School-Aged Children Bullying Working Group (2005). Bullying and symptoms among school-aged children: International comparative cross sectional study in 28 countries. European Journal of Public Health, 15, 128-132.

Durand-Zaleski, I., Scott, J., Rouillon, F., \& Leboyer, M. (2012). A first national survey of knowledge, attitudes and behaviours towards schizophrenia, bipolar disorders and autism in France. BMC Psychiatry, 12, 128.

Evans, S. (2013). What Vodafone sees in autistic people in Germany. BBC News. Retrieved from http://www.bbc.co.uk/news/world-europe-23270360.

Fein, D., Barton, M., Eigsti, I-M., Kelley, E., Naigles, L., Schultz, R.T., ... Tyson, K. (2013). Optimal outcome in individuals with a history of autism. Journal of Child Psychology and Psychiatry, 54 (2), 195-205.

Forsythe, L., Rahim, N., \& Bell, L. (2008). Benefits and employment support schemes to meet the needs of people with an autistic spectrum disorder. London: National Audit Office.

Ganz, M.L. 2007. The Lifetime Distribution of the Incremental Societal Costs of Autism. Archives of Pediatric \& Adolescent Medicine, 161(4), 343-349.

Gray, C. (2004). Gray's guide to bullying parts I-III. Jenison Autism Journal, 16(1), 219.

Helt, M., Kelley, E., Kinsbourne, M., Pandey, J., Boorstein, H., Herbert, M., \& Fein, D. (2008). Can children with autism recover? If so, how? Neuropsychology Review, 18, 339-366. Hill, E.L., \& Frith, U. 2003. Understanding autism: insights from mind and brain. Philosophical Transactions of the Royal Society B, 358, 281-289. 
Hodson, H. (2013). Rise of the autistic workforce. New Scientist. Retrieved from http://www.newscientist.com/article/mg21829194.300-rise-of-the-autisticwo\#.UjnwF9KsiSq

Howard, J.S., Sparkman, C.R, Cohen, H.G., Green, G., \& Stanislaw, H. (2005). A comparison of intensive behavior analytic and eclectic treatments for young children with autism. Research in Developmental Disabilities, 26, 359-383.

Howlin, P. (2013). 70 years of research on autism-how far have we come? Link Autism- Europe, $60,4-6$.

Howlin, P., Alcock J., \& Burkin C. (2005). An 8-year follow-up of a specialist support employment service for high-ability adults with autism or Asperger syndrome. Autism, 9(5), 533-549.

Howlin, P., Goode, S., Hutton, J. \& Rutter, M. (2004). Adult outcome for children with autism. Journal of Child Psychology and Psychiatry, 45(2), 212-229.

Huppert, J. (2013, June 21). The undiscovered workforce: why more employers should take on people with autism. Cambridge News. Retrieved from http://www.cambridgenews.co.uk/News/Blogs/House-Points/The-undiscovered-workforce-why-moreemployers-should-take-on-people-with-autism-20130621165954.htm.

Jordan, R. (2012). Autism, ABA and education. Consultation for Department of Health, Social Services, and Public Safety. Belfast: DHSSPS.

Keenan, M., Dillenburger, K., Doherty, A., Byrne, J., \& Gallagher, S. (2010). Experiences of parents during diagnosis and forward planning for children with Autism Spectrum Disorder. Journal of Applied Research in Intellectual Disabilities, 23, 390-397. 
Klin, A., Saulnier, C.A., Sparrow, S.S., Cicchetti, D.V., Volkmar, F.R., \& Lord, C. (2007). Social and Communication Abilities and Disabilities in Higher Functioning Individuals with Autism Spectrum Disorders: The Vineland and the ADOS. Journal of Autism and Developmental Disorders, 37, 748-759.

Knapp, M., Romeo, R., \& Beecham, J. (2009). Economic cost of autism in the UK. Autism, 13(3), 317-336.

Lamb, B. (2009). The Lamb enquiry. SEN and parental confidence. Retrieved from www.education.gov.uk.

Light it up Blue (2013) retrieved from www.lightitupblue.org/Markslist/home.do

Little, L. (2002). Middle-class mothers' perceptions of peer and sibling victimisation among children with Asperger's syndrome and non-verbal learning disorders. Issues in Comprehensive Pediatric Nursing, 25, 43-57.

Lloyd, K. (1994). Do as I say, not as I do. The Behavior Analyst, 17, 131-139.

Medical Research Council (2001). MRC review of autism research: Epidemiology and causes. London: Medical Research Council.

Mesibov, G.B., Shea, V., \& Schopler, E. (2004). The TEACCH Approach to Autism Spectrum Disorders. New York, NY: Springer.

National Autism Centre (2009).The National Standards Project - Addressing the need for evidence-based practice guidelines for autism spectrum disorders. Massachusetts, MA: National Autism Centre.

National Institute for Health and Care Excellence (2013). Autism: The management and support of children and young people on the autism spectrum. Retrieved from http://guidance.nice.org.uk/CG170/NICEGuidance/pdf/English 
Northern Ireland Executive 2012. Delivering the Bamford Vision 2012-2015. Retrieved from www.dhsspsni.gov.uk/2012-2015-bamford-action-plan.pdf

Office for National Statistics (2005). Mental health of children and young people in Great Britain, 2004. London: HMSO.

Orinstein, A.J., Helt, M., Troyb, E., Tyson, K.E., Barton, M.L., Eigsti, I-M., Naigles, L., \& Fein, D.A. (2014). Intervention for optimal outcome in children and adolescents with a history of Autism. Journal of Developmental and Behavioral Pediatrics, 0, 1-10.

Richman, W. L., Kiesler, S., Weisband, S. \& Drasgow, F. (1999). Journal of Applied Psychology, Vol 84 (5), 754-775

Rogers, S. (1996). Brief Report: Early Intervention in Autism. Journal of Autism and Developmental Disorders 26(2), 243-246.

Rosenblatt, M. (2008). I Exist: The message from adults with autism in England. Retrieved from www.autism.org.uk

Schofield, H. (2012). France's autism treatment 'shame'. BBC News Magazine. Retrieved from www.bbc.co.uk/news/magazine-17583123.

Siller, M. \&Sigman, M. (2002). The behaviours of parents of children with autism predict the subsequent development of their children's communication. Journal of Autism and Developmental Disorders, 32, 77-89.

Sofronoff, K., Dark, E., \& Stone, V. (2011). Social vulnerability and bullying in children with Asperger syndrome. Autism, 15, 355-372.

Solish, A., Perry, A., \& Minnes, P. (2010). Participation of children with and without disabilities in social, recreational and leisure activities. Journal of Applied Research in Intellectual Disabilities, 23, 226-236. 
Stewart, S. (2008). I Exist: The message from adults with autism in Northern Ireland. Belfast: The National Autistic Society. Retrieved 02/18 /2013 from www.autism.org.uk

Seltzer, M.M., Krauss, M.W., Shattuck, P.T., Orsmond, G., Swe, A. \& and Lord, C. (2003). The Symptoms of Autism Spectrum Disorders in Adolescence and Adulthood.Journal of Autism and Developmental Disorders, 33(6), 565-581.

Swearer S.M., Wang, C. Maag, J.W., Siebecker, A.B., \& Frerichs, L.J. (2012).Understanding the bullying dynamic among students in special and general education.Journal of School Psychology 50, 503-520.

Szatmari, P., Paterson, A.D., Zwaigenbaum, L., Roberts, W., Brian, J., Lui, X.-Q. .. Meyer, K.L. (2007). Mapping autism risk loci using genetic linkage and chromosomal rearrangements. Nature genetics, 39, 319-28.

Taggart, L., Truesdale-Kennedy, M., Ryan, A., \& McConkey, R., (2012). Examining the support needs of ageing family carers in developing future plans for a relative with an intellectual disability. Journal of Intellectual Disabilities, 16 (3), 217-234.

Thygesen, S. (2012). Ireland welcomes Specialisterne. Retrieved from http://specialistpeople.com/specialisterne-news/ireland-welcomes-specialisterne/

United Nations Convention on the Rights of Persons with Disabilities (UNCRPD; 2006). Strasbourg: Assembly of European Regions. Retrieved from www.un.org/esa/socdev/enable/rights/convtexte.htm.

United Nations Convention on the Rights of the Child (UNCRC; 1989). The rights of children with disabilities. General Comment No. 9 (2006). Geneva: United Nations.

United Nations Department of Economic and Social Affairs (2008). Creating an Inclusive Society: Practical Strategies to Promote Social Integration. Final Report of the Expert 
Group Meeting. Retrieved from http://www.un.org/esa/socdev/egms/docs/2008/Parisreport.pdf

United Nations Department of Economic and Social Affairs (2010). Analysing and Measuring Social Inclusion in a Global Context. Retrieved from http://www.un.org/esa/socdev/publications/measuring-social-inclusion.pdf

United Nations Educational, Scientific and Cultural Organisation (2013). Social inclusion policies: a plea for scientific and participatory evaluation. Retrieved from http://www.unesco.org/new/en/media-services/singleview/news/assessment_of_inclusive_policies_unesco_supports_evidence_based_approac hes_and_the_participation_of_the_populations_concerned/\#.UjoAJtKsiSo

United Nations (1995). Report of the World Summit for Social Development, Copenhagen, 6-12 March 1995. Retrieved from http://www.un-documents.net/aconf166-9.pdf.

van Roekel, E., Scholte, R. H. J., \& Didden, R. (2010). Bullying among adolescents with autism spectrum disorders: Prevalence and perception. Journal of Autism and Developmental Disorders, 40 (1), 63-73.

Vasagar, J. (2013, May 21). German multinational software firm targets recruitment of people with autism. The Telegraph. Retrieved from www.telegraph.co.uk/news/worldnews/europe/germany/10071558/Germanmultinational-software-firm-targets-recruitment-of-people-with-autism.html

Vismara, L.A. \& Rogers, S.J. (2010). Behavioral treatments in Autism Spectrum Disorder: What do we know? Annual Review of Clinical Psychology, 6, 447-468.

Warren Z., Veenstra-VanderWeele J., Stone W., Bruzek J.L., Nahmias A.S., Foss-Feig J.H. ... McPheeters M.L.. (2011).Therapies for Children With Autism Spectrum Disorders. 
Comparative Effectiveness Review No. 26. Rockville, MD: Agency for Healthcare Research and Quality.

Wilkinson, K. \&Twist, L. (2010). Autism and Educational Assessment: UK Policy and Practice. Slough: NFER.

Wilson, K., Mills, E., Ross, C., McGowan, J., \& Jadad, A. (2003). Association of autistic spectrum disorder and the measles, mumps and rubella vaccine: a systematic review of current epidemiological evidence. Archives of Pediatric and Adolescent Medicine, 157, $628-34$.

Yirmiya, N. \& Sigman, M. (2001).Attachment in children with autism. In J. Richer \& S. Coates (Eds.).Autism. The search for coherence. (pp. 53-63). London: Jessica Kingsley Publishers.

Zablotsky, B., Bradshaw, C.P., Anderson, C.M. \& Law, P. 2013. Risk factors for bullying among children with autism spectrum disorders. Retrieved from http://aut.sagepub.com/content/early/2013/07/29/1362361313477920 